\title{
TUNAS
}

JURNAL PENDIDIKAN GURU SEKOLAH DASAR

UMP

http://journal.umpalangkaraya.ac.id/index.php/tunas

Volume 5 Nomor 1, Desember 2019 (22-28)

\section{ANALISIS KESULITAN MENULIS RANGKUMAN MATA PELAJARAN BAHASA INDONESIA PADA PESERTA DIDIK KELAS IV SDN 2 PAHANDUT PALANGKA RAYA}

\section{An Analysis Of Students Difficulties In Writing Summary Of Indonesian Subjects} In Fourth Grade Students Of SDN 2 Pahanadut Palangka Raya

'Diplan, ${ }^{2}$ Dicky Tri Firmansyah dan ${ }^{3}$ Rini

Universitas Muhammadiyah Palangkaraya, Palangka Raya, Kalimantan Tengah, Indonesia

2Universitas Muhammadiyah Palangkaraya, Palangka Raya, Kalimantan Tengah, Indonesia

2Universitas Muhammadiyah Palangkaraya, Palangka Raya, Kalimantan Tengah, Indonesia

\section{ARTIKEL INFO}

Diterima

November 2019

Dipublikasi

Desember 2019

*e-mail :

Rini.azz63@gmail.com

\section{ABSTRAK}

Penelitian ini bertujuan untuk mengetahui kesulitan menulis rangkuman mata pelajaran Bahasa Indonesia pada peserta didik kelas IV SDN 2 Pahandut Palangka Raya Tahun Pelajaran 2018/2019. Subjek penelitian ini adalah peserta didik Kelas IV SDN 2 Pahandut Palangka Raya tahun pelajaran 2018/2019. Jenis penelitian ini adalah Kualitatif. Kehadiran peneliti sebagai instrumen utama dalam penelitian ini dan sekaligus sebagai pengumpul data. Teknik pengumpulan data yang digunakan adalah observasi, wawancara, dan dokumentasi. Analisis data terdiri dari analisis reduksi data, penyajian data, dan verifikasi/kesimpulan secara sistematis pada saat pelajaran menulis rangkuman di Kelas IV SDN 2 Pahandut Palangka Raya dilaksanakan dengan mengacu pada kemampuan peserta didik dalam menulis rangkuman yang mengalami kesulitan dipengaruhi oleh faktor internal dan faktor eksternal. Hasil penelitian yang dilaksanakan di Kelas IV SDN 2 Pahandut Palangka Raya dapat disimpulkan bahwa peserta didik yang mengalami kesulitan dalam menulis rangkuman dipengaruhi faktor internal dan faktor eksternal.

Kata kunci: Kesulitan Menulis Rangkuman.

\begin{abstract}
This research aims to determine the difficulties of writing summary of Indonesian subjects in fourth grade students of SDN 2 Pahandut Palangka Raya in academic year 2018/2019. The subject of this research were fourth grade students of SDN 2 Pahandut Palangka Raya in academic year 2018/2019. Type of the research was qualitative. The research as the main instrument in this research and at the time as data collectors. Data collection techniques were used observation, interview, and documentation. Data analysis were consisted of analysis of data reduction, data presentation, and verification/conclusion systematically during writing summary of Indonesian subjects in fourth grade students of SDN 2 Pahandut Palangka Raya carried out by reffered to the ability of students to write summary that had difficulties influenced by internal factor and external factor. The result of the research conducted in fourth grade students of SDN 2 Pahandut Palangka Raya can be concluded that the students who had difficulties in writing summary were influenced by internal factor and external factor.
\end{abstract}

Keywords: Difficulties Of Writing Summary. 


\section{Jurnal Pendidikan Guru Sekolah Dasar PENDAHULUAN}

Analisis dalam penelitian jenis apapun adalah merupakan cara berpikir, untuk mencari pola, karena berkaitan dengan pengujian secara sistematis terhadap sesuatu untuk menentukan bagian, hubungan antar bagian, dan hubungannya dengan keseluruhan. Analisis adalah penyelidikan terhadap suatu peristiwa (karangan, perbuatan, dan sebagainya) untuk mengetahui keadaan yang sebenarnya (sebab, musabab, duduk perkaranya, dan sebagainya). Untuk melaksanakan dan mencapai suatu tujuan pendidikan, tentunya di perlukan kerja sama dan dukungan dari semua pihak yang terkait. Pihak-pihak terkait mendukung dan bekerja sama untuk menciptakan pendidikan yang lebih baik dan menyeluruh bagi semua kalangan. Dengan adanya pendidikan yang baik dan didukung dengan sarana prasarana yang baik maka bukan hal yang tidak memungkinkan terwujudnya pendidikan yang di inginkan oleh semua pihak.

Dari data observasi pertama yang dilakukan peneliti pada tanggal 14 Januari 2019 di SDN 2 Pahandut pada mata pelajaran Bahasa Indonesia di kelas IV dan observasi kedua yang dilakukan peneliti pada tanggal 9 Mei 2019 peserta didik masih kesulitan membuat rangkuman dari sebuah cerita dan menentukan suatu ide pokok pada sebuah paragraf dan juga kesulitan menyederhanakan kalimat. Peserta didik cenderung langsung mengcopy kalimat yang ada pada cerita tanpa menguraikan dengan kalimat sendiri, dan cara merangkum biasanya ditulis dari awal paragraf sampai tanda titik pertama / kalimat pertama pada cerita. Pada aspek Berbahasa ada 4 keterampilan dalam berbahasa Indonesia yaitu keterampilan menyimak, membaca, berbicara, dan menulis. Menyimak dan membaca termasuk dalam kegiatan reseptif yaitu kegiatan yang bersifat menerima, sedangkan berbicara dan menulis merupakan kegiatan ekspresif dan produktif yaitu kegiatan yang bersifat menghasilkan. Keempat aspek ini merupakan satu kesatuan yang saling mendukung satu sama lain. Padahal kemampuan menulis dan merangkum sangat penting dan akan selalu ada dijenjang berikutnya. Salah satu bidang aktivitas yang memegang peranan penting dalam pembelajaran bahasa ialah menulis. Keterampilan menulis merupakan urutan yang terakhir dalam proses belajar bahasa setelah keterampilan menyimak, berbicara, dan membaca. Bila dibandingkan dengan ketiga keterampilan berbahasa lainnya, keterampilan menulis lebih sulit dikuasai. Hal ini karena diperlukan kemampuan untuk menguasai berbagai unsur kebahasaan dan unsur di luar bahasa itu sendiri yang akan menjadi isi tulisan. Baik unsur bahasa maupun unsur ini harus saling berkaitan sehingga tulisan menjadi runtut dan terpadu. Keterampilan menulis dapat dipandang sebagai salah satu keterampilan berbahasa yang kompleks. Kegiatan menulis, paling tidak melibatkan aspek penggunaan bahasa dan pengolahan isi. Bahkan jika dipandang sebagai bagian kemampuan komunikatif, kegiatan menulis melibatkan kompetensi gramatikal, kompetensi sosio linguistik, kompetensi discourse/ wacana, dan kompetensi strategik.

Tujuan pembelajaran menulis tentulah mengharapkan para peserta didik memiliki kemampuan dalam menulis. Meskipun telah disadari, bahwa penguasaan bahasa tulis mutlak diperlukan dalam kehidupan modern, namun dalam kenyataannya pengajaran keterampilan menulis kurang mendapat perhatian. Menulis adalah suatu cara mengekspresikan pikiran atau perasaan dalam bentuk tulisan. Dari uraian di atas dapat ditemukan fokus penelitiannya adalah sebagai berikut :

I. Apa penyebab kesulitan menulis rangkuman pada mata pelajaran Bahasa Indonesia di Kelas IV SD Negeri 2 Pahandut? 
Jurnal Pendidikan Guru Sekolah Dasar

2. Apa penyebab kesulitan menentukan ide pokok paragraf cerita pada mata pelajaran

Bahasa Indonesia di kelas IV SDN 2 Pahandut?

Dalam Jurnal Pendidikan Pembelajaran Bahasa Indonesia dan Sastra (vol 2, no I: 20I8) bahasa merupakan kebutuhan setiap umat manusia. Bahasa juga merupakan salah satu unsur budaya dan simbol bagi manusia dalam berkomunikasi terhadap semua kebutuhan. Melalui bahasa, manusia dapat menyampaikan atau menerima berbagai pesan, baik untuk dirinya maupun untuk orang lain. Bahasa dalam lingkup yang sangat luas tidak hanya tertuju pada bahasa lisan atau bahasa tertulis.

Menulis merupakan salah satu keterampilan berbahasa yang sangat ekspresif dan produktif. Dikatakan sebagai ekspresif karena, menulis merupakan hasil pikiran dan perasaan yang dapat dituangkan melalui aktivitas menggerakkan motorik halus melalui goresan-goresan tangan kita. Selanjutnya, dikatakan produktif, karena merupakan proses dalam menghasilkan satuan bahasa berupa karya nyata, hingga lahir dalam bentuk tulisan. Dengan demikian, secara umum tulisan disebut sebagai karya dari hasil gagasan seseorang yang dapat dipahami oleh orang lain.

Berbicara mengenai tulisan, dalam hal ini, Gie (200I: 25-30) mengelompokkan tulisan atas beberapa kriteria, salah satu kriterianya adalah berdasarkan ragamnya, yakni; tulisan faktawi (faktual) dan tulisan khayali (imajinasi). Sejalan dengan pendapat di atas, tulisan atau karya menurut Lamuddin (1993; 2II) menjelaskan bahwa, jika dilihat berdasarkan bobotnya, maka tulisan terbagi atas; (I) ilmiah; (2) semiilmiah/ popular; (3) nonilmiah.

Graves (dalam Akhadiah dkk., 1998:1.4) berkaitan dengan manfaat menulismengemukakan bahwa: (I) menulis mengasah kecerdasan, (2) menulis mengem-bangkan daya inisiatif dan kreativitas, (3) menulis menumbuhkan keberanian, dan (4) menulis mendorong kemauan dan kemampuan mengu Menyajikan sebuah tulisan dari seorang pengarang ke dalam sebuah sajian tulisan yang ringkas bukan hal yang mudah. Kita harus membaca dengan cermat dan memerhatikan ketika kita harus menuliskannya secara ringkas. Hal ini berkaitan dengan upaya kita untuk menangkap gagasan atau ide dari pengarang. Langkah meringkas bisa kita pakai untuk mengetahui maksud dan tujuan pengarang juga dalam rangka menyajikan sebuah tulisan ke dalam bentuk yang ringkas, padat, dan tetap berpatokan pada ide asli pengarang.

Dalam hal ini, yang harus kita perhatikan dalam membuat sebuah rangkuman adalah mempertahankan urutan asli dari ide asli pengarang. Akan tetapi, jangan kita mencampuradukkan pengertian tersebut ketika kita akan membuat sebuah ikhtisar. Patokan akan kedua hal tersebut ada perbedaannya. Dalam membuat ikhtisar, kita tidak perlu mempertahankan urutan karangan asli dan tidak perlu memberikan isi dari seluruh karangan itu secara proporsional (Keraf 1984:262).

Gorys Keraf mengemukakan bahwa membuat rangkuman dapat berguna untuk mengembangkan ekspresi serta penghematan kata. Latihan membuat rangkuman, menurut beliau, akan mempertajam daya kreasi dan konsentrasi si penulis rangkuman tersebut. Penulis rangkuman dapat memahami dan mengetahui dengan mudah isi karangan aslinya, baik dalam penyusunan karangan, cara penyampaian gagasannya dalam bahasa dan susunan yang baik, cara pemecahan suatu masalah, dan lain sebagainya.

\section{METODOLOGI PENELITIAN}

Peneliti melakukan penelitian di SDN 2 Pahandut Jl. Langsat Kecamatan Pahandut Kota 
Jurnal Pendidikan Guru Sekolah Dasar

Palangkaraya dan waktu penelitian dilakukan pada bulan Februari sampai bulan Mei 2019.

Menurut Diplan dan Andi (2018:32) penelitian kualitatif tidak ada batasan jarak dengan antara penelitian dan yang diteliti. Hubungan yang terjadi dalam penelitian kualitatif berdasarkan adanya rasa percaya diantara peneliti dan yang diteliti. Ketika dilapangan peneliti melakukan hubungan intens dengan maksud untuk mendekatkan diri dan bisa mendapatkan data yang lebih mendalam.

Kesulitan Peserta didik pada materi menulis rangkuman dan ide pokok suatu cerita. Dalam hal ini, berdasarkan hasil wawancara dengan wali kelas IV di SDN 2 Pahandut peserta didik bosan pada saat materi menulis, dan terkadang peserta didik sibuk sendiri sehingga tidak bisa menangkap materi yang telah disampaikan oleh guru, dan beberapa peserta didik belum bisa membaca meskipun sudah di kelas IV sehingga menyulitkan guru untuk memberikan materi. Dari data observasi juga terlihat banyak beberapa peserta didik belum tau sama sekali pengertian tentang menulis rangkuman. Jadi, pertama kali, peneliti masuk ke lapangan melakukan observasi atau pengamatan di sekolah mendalami penyebab peserta didik mengalami kesulitan menulis rangkuman pada mata pelajaran bahasa Indonesia di kelas IV SDN 2 Pahandut. Penelitit mencatat semua hasil pengamatan dan wawancara dalam catatan lapangan, kemudian peneliti melakukan analisis untuk menentukan informasi, data dan keterangan apalagi yang dibutuhkan. Begitu seterusnya sampai data jenuh atau mentok.

Menurut Diplan dan Andi (2018:24) Pendekatan Kualitatif memfokuskan kepada makna, pemahaman, praktis, penalaran, definisi suatu situasi tertentu, terkait dengan hal yang berhubungan dengan kehidupan sehari-hari.

Menurut Diplan dan Andi (2018:3I) data yang didapat dalam penelitian kualitatif dapat berupa gejala-gejala yang dinampakan dalam bentuk seperti foto, doumen, artefak ataupun berupa catatan-catatan lapangan pada saat penelitian. Dalam penelitin kualitatif dalam penentuan sampel (subjek) bukan berdasarkan banyaknya jumlah subjek tetapi lebih kepada kualitas dari subjek penelitian yang diambil.

Sumber pengumpulan data yang dilakukan peneliti dengan mempelajari berbagai data tertulis (dokumentasi), buku-buku, laporan, maupun datadata lainnya merupakan data sekunder dalam penelitian. Dalam penelitian ini sumber data dibagi menjadi 2 bagian yaitu:

I. Sumber data primer adalah peserta didik kelas IV

2. Sumber data pendukung sekunder adalah guru wali kelas IV, guru Bahasa Indonesia.

Menurut Diplan dan Andi (2019: 3I) apabila penelitian dilakukan dengan pendekatan kualitatif, maka yang bersangkutan akan menggunakan teknik observasi atau dengan melakukan observasi terlibat lagsung. Metode pengumpulan data adalah cara-cara yang dapat digunakan oleh peneliti untuk mengumpulkan data. Penelitian ini menggunakan metode pengumpulan data yakni observasi (pengamatan), wawancara, dan dokumentasi.

Analisis data dalam penelitian kualitatif, dilakukan pada saat pengumpulan data berlangsung, dan setelah selesai pengumpulan data dalam periode tertentu. Pada saat wawancara, peneliti sudah melakukan analisis terhadap jawaban yang di wawancara setelah dianalisis terasa belum memuaskan, maka peneliti akan melanjutkan pertanyaan lagi, sampai tahap tertentu, diperoleh data kriabel. Miles and Huberman (dalam sugiyono, 2016: 337) menyatakan bahwa:

"Aktivitas dalam analisis data kualitatif dilakukan secara interaktif dan berlangsung secara terus 
Jurnal Pendidikan Guru Sekolah Dasar menerus sampai tuntas, sehingga datanya sudah jenuh. Aktivitas dalam analisis data, yaitu data reduction, data display, dan conclusion drawing/verification.

\section{HASIL DAN PEMBAHASAN}

Temuan penelitian ini didapat berdasarkan hasil observasi dan wawancara dari pihak sekolah diantaranya Kesiswaan, Guru Kelas dan Peserta didik kelas IV dalam menganalisis kesulitan menulis rangkuman.

Jum'at 15 Maret 2019, pelaksanaan observasi pada pembelajaran bahasa Indonesia pada kelas IV di SD Negeri 2 Pahandut Palangka Raya, pada saat di amati dari kegiatan menulis rangkuman beberapa peserta didik masih tidak bisa merangkai dengan kata-katanya sendiri. Ada pula sebagian tidak tahu cara menulis rangkuman, dan sebagian peserta didik belum bisa menentukan ide pokok pada suatu paragraf dan ada beberapa yang belum bisa sama sekali membaca dan menulis padahal sudah dikelas IV SD. Namun dibiarkan oleh guru kelas tanpa ada penangan atau bimbingan khusus kepada peserta didik yang belum bisa membaca. Oleh karena itu, peneliti melakukan penelitian untuk mengatahui permasalahan tersebut.

Tabel 8 Hasil Observasi

Analisis Kesulitan Menulis rangkuman

\begin{tabular}{|c|c|c|c|c|}
\hline No & $\begin{array}{c}\text { Aspek yang } \\
\text { Diamati }\end{array}$ & Indikator & $\begin{array}{c}\text { Kode } \\
\text { Peserta } \\
\text { Didik }\end{array}$ & Keterangan \\
\hline \multirow[t]{4}{*}{ I } & \multirow[t]{4}{*}{$\begin{array}{l}\text { Faktor } \\
\text { Internal }\end{array}$} & $\begin{array}{ll}\text { a. } & \text { Menentukan ide } \\
\text { pokok bacaan }\end{array}$ & $\mathrm{AP}, \mathrm{SP}$ & $\begin{array}{l}\text { Peserta didik masih belum } \\
\text { bisa menentukan ide pokok }\end{array}$ \\
\hline & & $\begin{array}{l}\text { b. Kemampuan dalam } \\
\text { mereproduksi kata }\end{array}$ & $\mathrm{AP}, \mathrm{SP}$ & $\begin{array}{l}\text { Kebanyakan peserta didik } \\
\text { masih belum paham } \\
\text { mengolah kata }\end{array}$ \\
\hline & & $\begin{array}{l}\text { c. } \text { Ketepatan kalimat } \\
\text { dalam menulis } \\
\text { ringkasan isi bacaan }\end{array}$ & $\mathrm{AP}, \mathrm{SP}$ & $\begin{array}{l}\text { Peserta didik belum } \\
\text { sepenuhnya tepat dalam } \\
\text { merangkai kalimat saat } \\
\text { menulis ringkasan }\end{array}$ \\
\hline & & $\begin{array}{ll}\text { d. } & \text { Menulis rangkuman } \\
\text { menggunakan } \\
\text { kalimatnya sendiri }\end{array}$ & $\mathrm{AP}, \mathrm{SP}$ & $\begin{array}{l}\text { Keterbatasan kata peserta } \\
\text { didik sehingga mereka } \\
\text { kesulitan merangkum } \\
\text { menggunkan kalimatnya } \\
\text { sendiri }\end{array}$ \\
\hline 2 & $\begin{array}{l}\text { Faktor } \\
\text { eksternal }\end{array}$ & $\begin{array}{l}\text { a. Kurangnya perhatian } \\
\text { orang tua terhadap } \\
\text { keberhasilan belajar }\end{array}$ & $\mathrm{AP}$ & $\begin{array}{l}\text { Beberapa orangtua sebagian } \\
\text { ada yang memberikan } \\
\text { perhatian khusus untuk } \\
\text { anaknya dan juga ada yang } \\
\text { tidak mau tau dengan } \\
\text { anaknya dirumah. }\end{array}$ \\
\hline
\end{tabular}


Jurnal Pendidikan Guru Sekolah Dasar

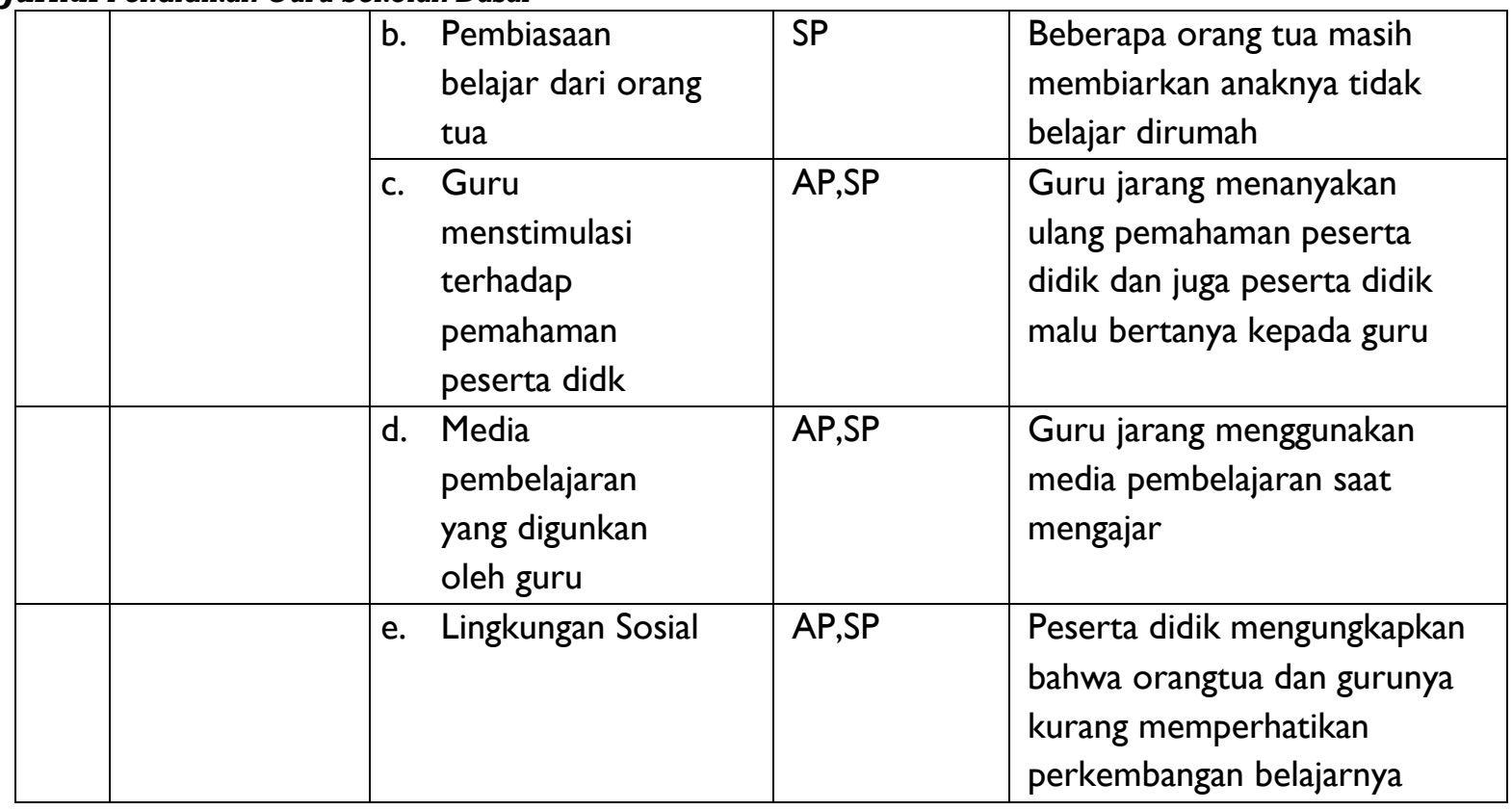

Berdasarkan tabel di atas dapat di analisis kesulitan menulis membuat rangkuman itu masih belum bisa dikatakan mampu dikarenakan masih ada yang belum bisa menulis rangkuman, dan belum bisa menentukan ide pokok bacaan dapat dilihat pada saat menulis rangkuman kebanyakan peserta didik menulis ulang bacaan tanpa menentukan ide pokok bacaan. Selain itu, yang dikatan mampu menulis rangkuman peserta didik harus bisa menyajikan singkat dari suatu karangan asli tetapi tetap mempertahankan urutan isi dan sudut pandang pengarang asli dan dijadikan sebuah paragraf.

Keabsahan data di dapat dari hasil wawancara peserta didik, wawancara guru kelas, dan wawancara bagian kesiswaan, hasil wawancara tersebut menunjukan bahwa ada beberapa peserta didik kelas IV SDN 2 Pahandut Palangka Raya yang mengalami kesulitan dalam menulis rangkuman.

Berdasarkan hasil observasi dan wawancara diatas maka dapat dianalisis bahwa ada banyak faktor-faktor yang mempengaruhi kesulitan dalam menulis rangkuman antara lain masih kesulitan dalam menentukan ide pokok suatu bacaan, sulit dalam mereproduksi kalimat, tidak tepat dalam menggunakan kata untuk dijadikan sebuah kalimat, masih tidak terbiasa menulis rangkuman dengan kalimat sendiri, dan ada faktor eksternal yang mempengaruhi peserta didik antara lain dari lingkungan keluarga yaitu kurangnya perhatian orang tua, kurangnya pembiasaan belajar mandiri di rumah, dari lingkungan belajar maupun di sekolah yaitu kurangnya pemanfaatan media dalam mengajar, serta kurangnya umpan balik dari guru ke peserta didik.

\section{SIMPULAN}

Berdasarkan hasil penelitian yang telah dilakukan oleh peneliti, maka dapat di ambil kesimpulan yang berkaitan dengan Tujuan penelitian yaitu penyebab kesulitan menulis rangkuman pada mata pelajaran Bahasa Indonesia di Kelas IV SD Negeri 2 Pahandut kegiatan proses pembelajaran Bahasa Indonesia khususnya menulis rangkuman di SDN 2 Pahandut Palangka Raya adalah ada ada beberapa peserta didik yang 


\section{TUNAS}

Jurnal Pendidikan Guru Sekolah Dasar

belum bisa membaca dan menulis dan setiap guru menerangkan pesrta didik sering bermain dan berbicara sendiri. Penyebab kesulitan menentukan ide pokok paragraf cerita pada mata pelajaran Bahasa Indonesia di kelas IV SDN 2 Pahandut Aktivitas pembelajaran Bahasa Indonesia khususnya dalam kegiatan menentukan ide pokok paragraf cerita kurang maksimal. Ada beberapa faktor yang mempengaruhi, antara lain faktor internal maupun faktor eksternal. Dari segi ini, orang tua, guru, maupun lingkungan sosial peserta didik turut ikut berperan dalam menentukan hasil atau kemampuan peserta didik.

\section{DAFTAR PUSTAKA}

A.M, Sardiman. (20/4). Interaksi dan Motivasi Belajar. Jakarta : Rajawali Pers.

Akhadiah, Sabarti. (1998). Pembinaan Kemampuan Menulis Bahasa Indonesia. Jakarta : Erlangga

Anas, Sudijono. (20/2). Pengantar Evaluasi Pendidikan. Jakarta : PT Raja Grafindo Persada.

Asih, Retno. (2008). Peningkatan Menulis Rangkuman dengan Pendekatan Konstekstual Komponen Inkuiri Melalui Media Surat Kabar Pada Siswa Kelas VIII C SMP Islam Ungaran Tahun 2008/2009. Universitas Negeri Semarang.

Basrowi, dan Suwandi. (2008). Memahami Penelitian Kualitatif. Jakarta : Rineka Cipta

Diplan, dan Andi. (20/8). Metodologi Penelitian Kualitatif. Jawa Tengah. CV. Sarnu Untung Djuharie, dan Suherli. Panduan Membuat Karya Tulis. Bandung : Yrama Widya

Gie, The Liang. (2002). Terampil Mengarang. Yogyakarta : Balai Pustaka

Harimurti, Kridalaksana. (200I). Kamus Linguistik. Jakarta : Gramedia Haryanto. (2000). Metode Penulisan dan Penyajian Karya Ilmiah. Jakarta : EGC 